\title{
Sandflies in the Greater Athens Region, Greece
}

\author{
PAPADOPOLLOS 13.* AND TSELENTIS Y.*
}

\section{Summary :}

During the period from May to October 1992, a survey of phlebotomine sandflies was conducted in the Greater Athens region where cases of human and canine leishmaniasis occur. Using cas tor-oil paper traps, a total of 3015 sandflies were caught. Of the identified specimens, 1002 (34. 1\%) were Phlebotomus neglectus $541(18.4 \%)$ were $P$. papatasi, $182(6.2 \%)$ were P. tobbi, 50 (1.7\%) were $P$. simici, $30(1.0 \%)$ were $P$. alexandri, $1310.4 \%)$ were $P$. sergenti and $1122(38.2 \%)$ were Sergentomyia minuta. The seasonal activity of most Phlebotomus species was bimodal while that of S. minuta was unimodal. The population density of sandflies varied significantly in different localities; it was low in most of the stations and high in some stations in the outskits. Among the potential vectors of Leishmania spp., P. neglectus and $P$. papatasi were the most widespread species. The former species showed high density in 12 of the 70 sampled stations, while the latter in only 4 . Hence, the risk of transmission of sandfly-borne diseases is still present in the Greater Athens region.

KEY WORDS sandflies, distribution, seasonal activity, Greece,

MOTS CLES : Phlébotomes. distribution. activité saisonnière Grèce.

\section{INTRODUCTION}

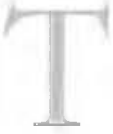

he Greater Athens region is one of the endemic areas of visceral leishmaniasis (VL) in Greece (Orphanidis, 1979; Tselentis et al., 1979: Tzamouranis, 1979). Human and canine cases of Kala-azar were reported in this region early in this century (Cardamatis, 1911, 1912; Aravandinos, 1916; Caminopetros, 1934), as well as an epidemic of papatasi fever (Cardamatis, 1931). Statistics of the Greek Ministry of Health for the period 1966-1991, showed that $57.9 \%$ of all human VL cases in Greece originated in Athens. Piraeus and their suburbs. A retrospective study conducted in the same region in the 70 's recorded an increase of the clinical VL cases since the decade of 1960 and pointed out that $75 \%$ of the infected persons were living on or near the slopes of the mountains surrounding the Athens Basin and the hills situated in it Corphanidis, 1979; Tselentis et al., 1979). It was also observed that many of the cases

\footnotetext{
" Laboratory of Clinical Bacteriology, Parasitology, Zoonoses and Geographic Medecine. Division of Medicine, University of Crete, Iraklion. Crete. Greece
}

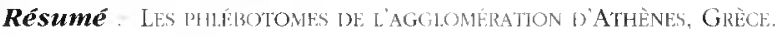
Pendant la période de mai à octobre 1992, une étude sur les phlébotomes a été entreprise dans l'agglomération d'Athènes ou existent des cas de leishmaniose humaine et canine. Au total, 3015 phlébotomes ont été capturés par la méthode des pièges adhésifs. Ont été identifiés: Phlebotomus neglectus: $1002(34,7 \%), P$. papatasi $541(18,4 \%)$, P. tobbi : $182(6,2 \%)$, P. simici $50(1,7 \%), P$ alexandri : $30(1,0 \%)$, P. sergenti : $13(0,4 \%)$ et Sergentomyia minuta : $1722(38,2 \%)$.

L'activité saisonnière de la plupart des espèces du genre Phlebotomus montre une évolution diphasique, randis que celle de S. minuta est monophasique. La densité des populations de phlébotomes varie largement dans les différentes localités prospectées; elle est basse dans la majorité des stations et élevée dans certaines stations périphériques. Parmi les vecteurs potentiels de Leishmania spp., $P$. neglectus et $P$. papatasi sont les espèces les plus répandues. Le premier présente une haute densité dans 12 des 70 sta tions prospectées, le second seulement dans 4 d'entre elles. Ainsi, le risque de la transmission de maladies par les phlébotomes reste présent dans l'agglomération d'Athènes.

occurred in the vicinity of quarries. According to Veterinarian Services leishmania infections in dogs are common in the region. Tzamouranis et al. (1984), succeeded in isolating the parasites causing human and canine VL, and identified them as Leishmania infantum.

According to Rioux et al. (1977), the principal determinant of the focus of leishmaniasis in the Mediterranean region is the vector. Therefore, the presence and abundance of certain sandfly species in an area could indicate the occurrence of this parasitic infection. Twelve sandfly species, in 2 genera and 5 subgenera, are known to be present in Greece (Léger et al., 1986). The sandflies in the region of Athens were studied in the 30's by Cardamatis (1931), Caminopetros $(1934 ; 1935)$ and Adler and Theodor (1935). After World War II two additional studies were undertaken to evaluate sandfly density after the extensive spraying with residual insecticides to control anopheline mosquitoes (Hertig, 1949; Hadjinicolaou, 1958). All these studies were limited to a few localities in the Greater Athens area and were of short duration, mainly conducted in July and 
M O U N T

P $\quad E \quad N \quad T \quad E$ L I

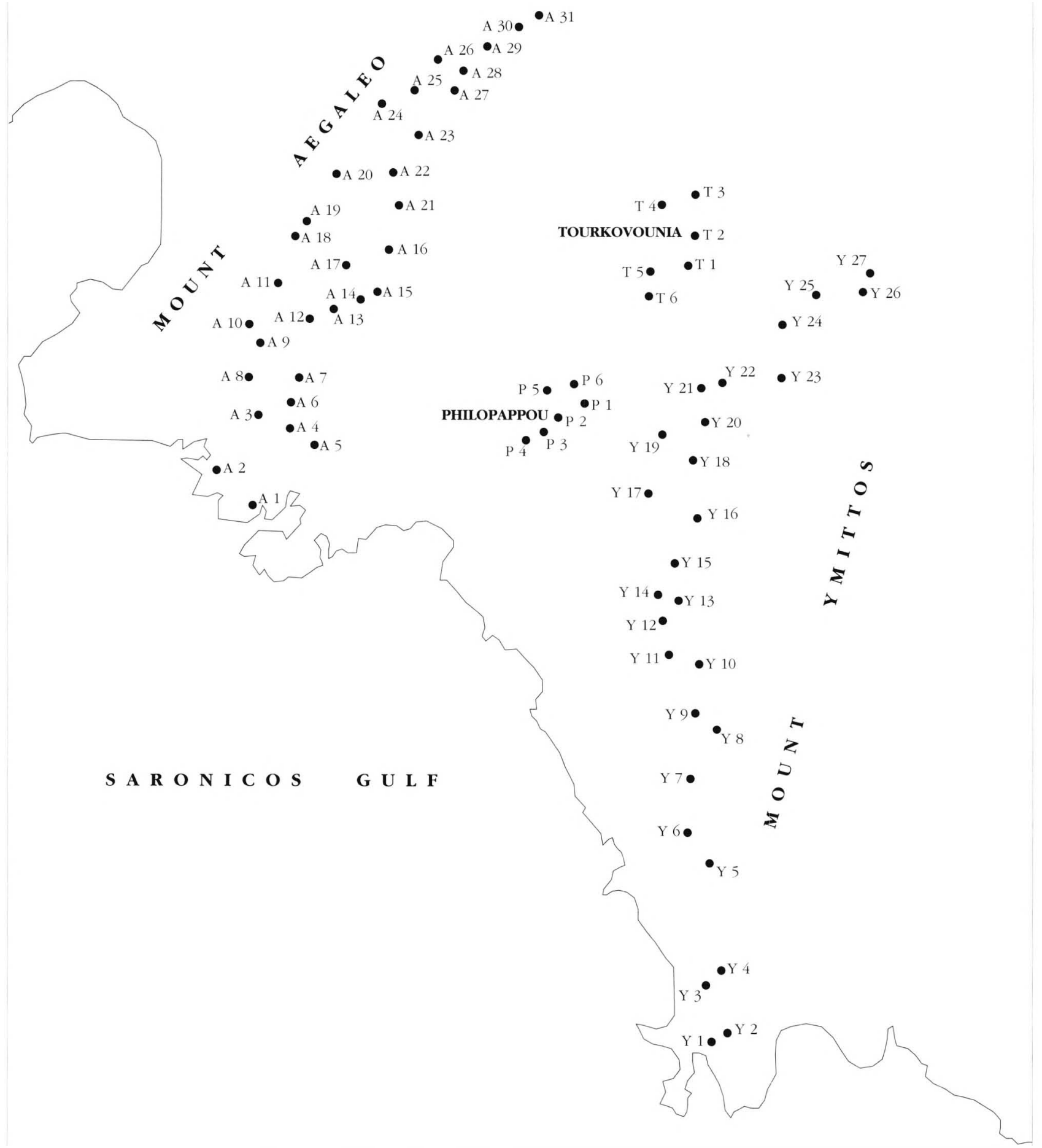

Fig. 1. - Stations in which the survey was carried out in the Greater Athens region. 
August. In addition, the extensive construction and expansion of the city to the foothills of the surrounding mountains and the hills inside it, clue to the rapidly increasing population, resulted in a highly modified landscape in the last 35 years, which undoubtedly changed the distribution of sandflies.

In this paper the results of an extensive survey on the sandfly population carried out in Athens, Piraeus and their suburbs, cluring the period May-October 1992, are presented.

\section{STUDY AREA}

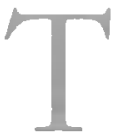

he Greater Athens region, consisting of the cities of Athens, Piraeus and their suburbs, is part of the prefecture of Attica. The study area is situated between $37^{\circ} 47^{\prime}-38^{\circ} 05^{\circ} \mathrm{N}$ and $23^{\circ} 36^{\circ}-$ $23^{\circ} 50^{\circ} \mathrm{E}$. It belongs to the pronounced mesomediterranean bioclimatic zone (Mavrommatis, 1980). It is delimited on the east by Mount Ymittos $(1026 \mathrm{~m})$, on the northeast by Mount Penteli $(1108 \mathrm{~m})$, on the north-west by Mount Parnis ( $1413 \mathrm{~m}$ ), on the west by Mount Aegaleo $(452 \mathrm{~m})$ and on the south by the Saronicos Gulf. It is a highly built-up area with a large population. About one-third of the total Greek population of 10 millions resides here. During the last years, due to an intense urbanization, the suburbs have been expanded on the slopes of the mountains surrounding the city.

Seventy (70) stations, situated at between $20 \mathrm{~m}$ and $300 \mathrm{~m}$ altitude and distributed in the following 4 transects, were selected to sample sandflies. The transects were selected in such a way as to reach the foothills where most of the cases of VL have occurred (Fig. 1).

East transect ( 27 stations): On the southeast slopes of Mount Ymittos.

West transect (31 stations): On the southwest slopes of Mount Aegaleo.

Center 1 transect ( 6 stations) : On and around the hill of Tourkovounia $(337 \mathrm{~m})$.

Center 2 transect ( 6 stations) : On and around the hill of Philopappou $(160 \mathrm{~m})$ and the rock of Acropolis.

The distance between two neighbouring stations varied from $300 \mathrm{~m}$ to $3 \mathrm{Km}$.

\section{MATERIAL AND METHODS}

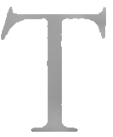

he survey was carried out from May to October 1992. The preparatory steps for this study were conducted during the month of May. In this month, the study was limited to the east and center 1 transects. In June, it was expanded to include the rest. The stations were visited once per month.

Sandflies were caught by the use of castor-oil treated paper sheets $(21 \times 29.7 \mathrm{~cm})$. A total of 6050 castoroiled treated paper sheets were set and 5830 of them were recovered (losses 3.6\%). The sticky traps (10 to 20 traps/station) were placed into any potential sandfly breeding or resting site (holes or cracks in dry walls, buttresses or rocks; spaces in stone walls; pipes of buildings, gardens or park walls). This sampling method is considered to be the most suitable for ecological studies on sandflies in a wide area (Rioux et al., 1982). The papers were left in place for 3 days. In the laboratory, the specimens were picked up with a fine paint-brush, washed in $90 \%$ ethanol, cleared in Marc-André solution and mounted in Faurés Gum Chloral for identification.

The identification of male sandflies was based on the morphology of their external genitalia, while the identification of the females was based on the morphology of spermathecae, pharynges and cibaria, according to the descriptions of Léger et al. (1986).

To compare the capture results in the different sites, the number of collected sandflies per papertrap (sf/pt) per month and station was calculated. The mean of these monthly values represents the number of $\mathrm{sf} / \mathrm{pt}$ for the station during the entire period (mean monthly density). We prefer to express the sandfly density as sf/pt rather than as $\mathrm{sf} / \mathrm{m}^{2}$, a method used by other authors (Rioux et al., 1967; Croset et al., 1977), because the sheets of paper were often put in place folded, twisted or rolled up in the holes and cracks. So, the total available surface of the paper was not always the same in all situations.

\section{RESULTS}

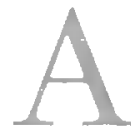

total of 3015 sandflies was collected during the entire period of study. Of these, 75 were so damaged that it was impossible to identify them with certainty. Table I shows the identified species, their number and percent of total, percent of females for each species and the number of localities they were found, while Figures 2 to 4 show their distribution and maximum monthly density (number of sf/pt observed in the month of the highest density).

All but 6 stations were positive, at least once, for sandflies. Phlebotomus neglectus was the most widespread species (Fig. 3). P. papatasi and S. minuta, present in more than $50 \%$ of all the stations, as well as $P$. tobbi, present in about $40 \%$ of them, had a rather even distribution (Figs. 2, 3 and 4). P. simici and $P$. alexandri were totally absent from the stations 
M O U N T

$\begin{array}{lllllll}P & E & N & T & E & L & I\end{array}$

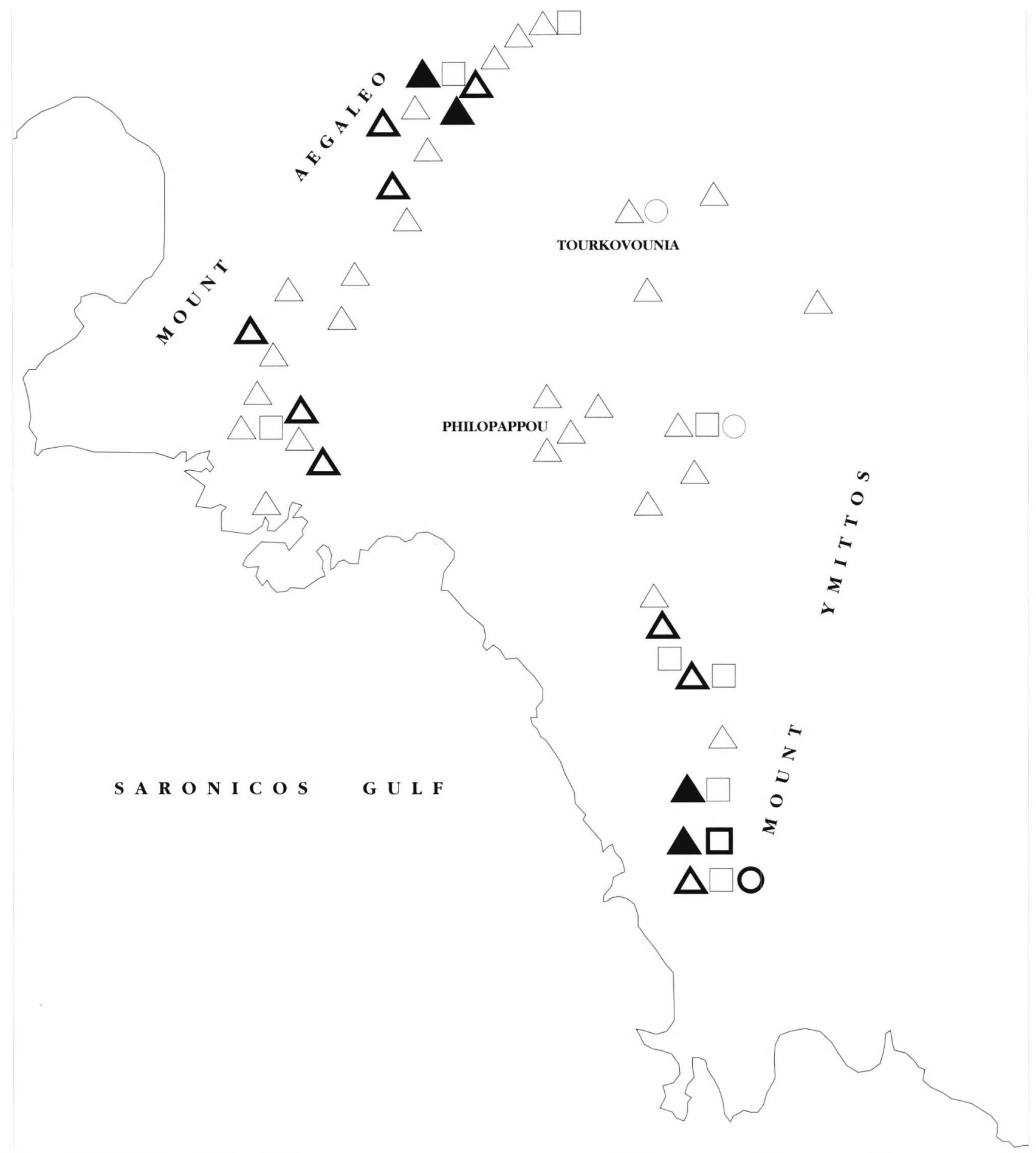

Fig. 2. - Distribution and maximum monthly density of Pblebotomus (Pblebotomus) papatasi ( $\triangle$ ), P. (Parapblebotomus) alexandri ( $\square$ ) ind P. (Paraphlebotomus) sergenti $(\bigcirc)$.

Legend : max monthly density $(\triangle \square \bigcirc)<0.25 \mathrm{sf} / \mathrm{pt}, \Delta \square \mathrm{O}) 0.25-1 \mathrm{sf} / \mathrm{pt},(\boldsymbol{\Lambda})>1 \mathrm{sf} / \mathrm{pt}$. 
$M O U N T$

P E N T E L I

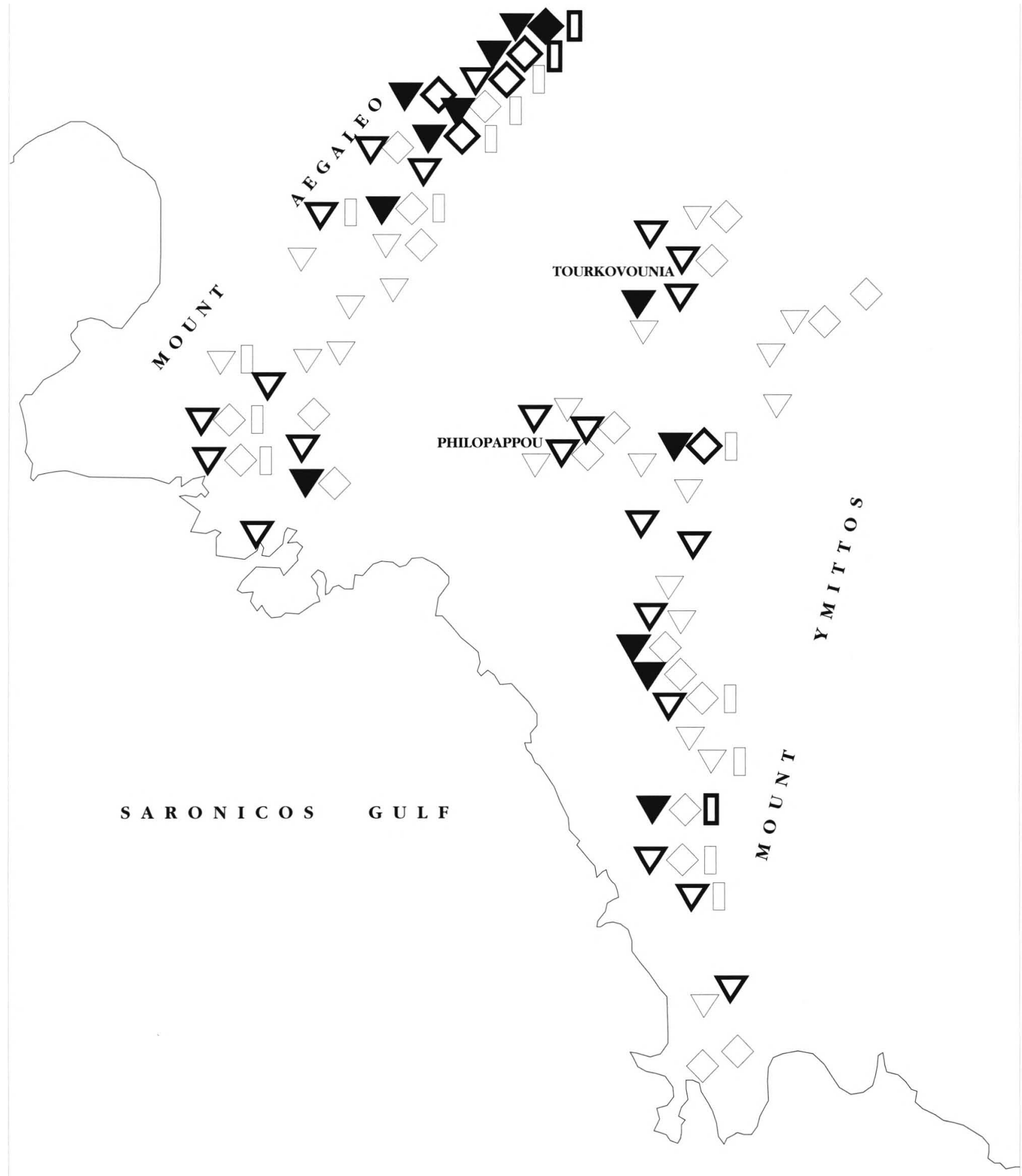

Fig. 3. - Distribution and maximum monthly density of Phlebotomus (Larroussius) neglectus $(\nabla), P$. (Larroussius) tobbi $(\bigcirc)$ and $P$, (Alderius) simici ( $\square$ )

Legend : max monthly ciensity $(\nabla<, \Pi)<0.25 \mathrm{sf} / \mathrm{pt},(\nabla \diamond \square) 0.25-\mathrm{lsf} / \mathrm{pt},(\boldsymbol{\nabla}\rangle)>1 \mathrm{sf} / \mathrm{pt}$ 
$\begin{array}{lllll}\mathbf{O} & \mathbf{U} & \mathbf{N} & \mathbf{T}\end{array}$

$\begin{array}{lllllllllllllll}\mathbf{P} & \mathbf{E} & \mathbf{N} & \mathbf{T} & \mathbf{E} & \mathbf{L} & \mathbf{I}\end{array}$

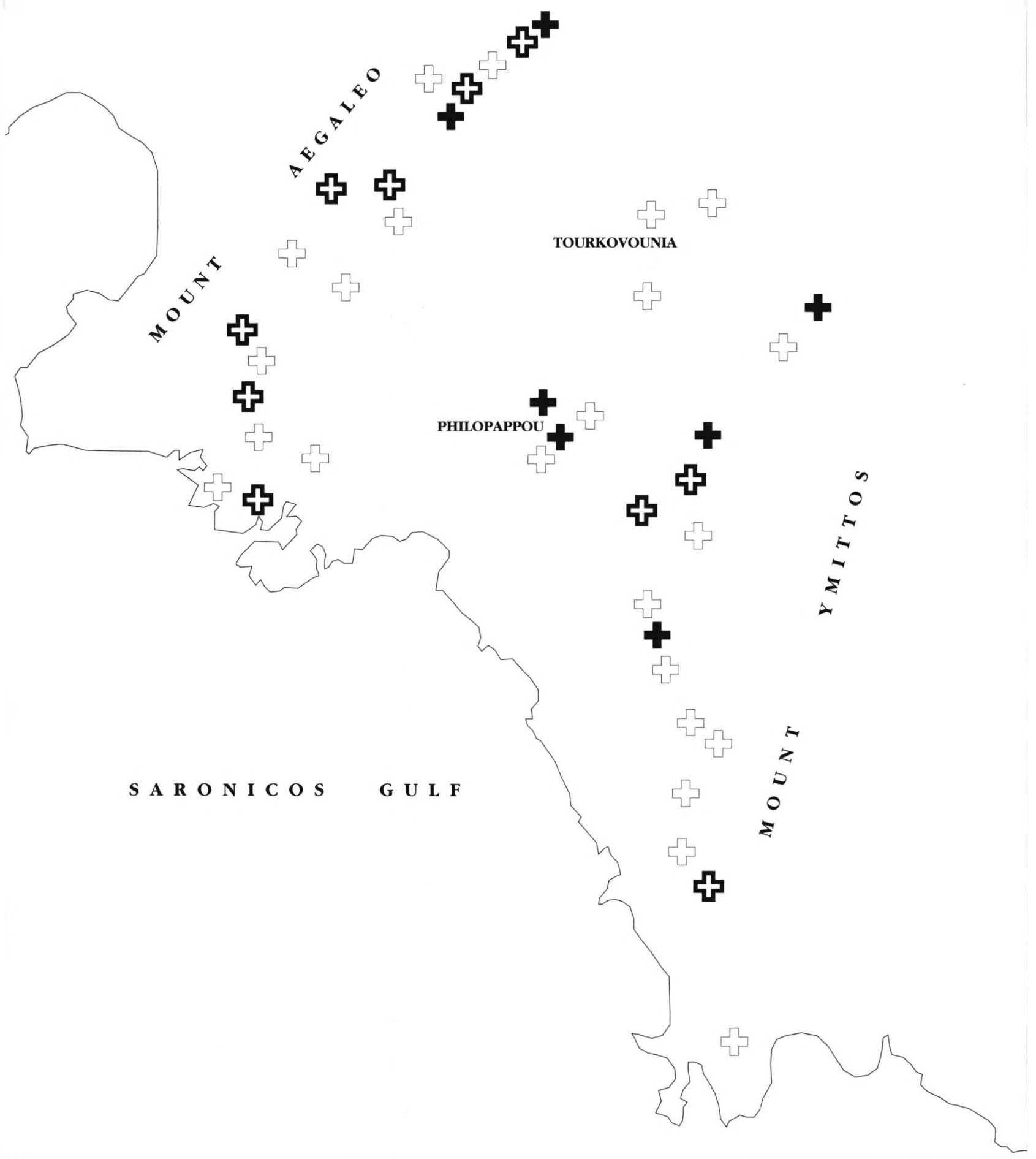

Fig. 4. - Distribution and maximum monthly density of Sergentomyia (Sergentomyia) minuta Legend : max monthly density $\left(\zeta^{2}\right)<0.25 \mathrm{sf} / \mathrm{pt}$, (引) $0.25-1 \mathrm{sf} / \mathrm{pt}$. (中) $>1 \mathrm{sf} / \mathrm{pt}$. 
of the center transects and generally had an uneven distribution (Figs. 2 and 3). P. sergenti was found only in 3 stations. The sex ratio of the captured specimens was strongly in favour of males, especially for Phlebotomus spp. (Table I).

A high variability was observed concerning the number of $\mathrm{st} / \mathrm{pt}$ in the various stations. The mean number of sf pt was similar for the ealst and west transects. However, the mean number of Phlebotomus spp./pt was higher in the west transect and that of Sergentomyia sp./pt in the east transect (Table II). The former is due to the relative abundance of Pblebotomus spp. in the stations in the north part of the west transect $(2.2-6.4 \mathrm{sf} / \mathrm{pt})$, while the latter is attributed to the abundance of Sergentomyia mimita in the station Y20 (14.8 sf/pt).

The seasonal activity of Phlebotomus spp. was bimodal and reflected in some way the seasonal activities of the three most numerous members of the genus in this region, i.e. P. neglectus, $P$. tobbi and P. papatasi (Fig. 5). The two peaks of activity for $P$. neglectus were in June and in October. while the peaks for $P$. papatasi were in July and in September. The bimodal activity of $P$. tobbi was not pronounced; and for this species too, a significant drop was observed in August. P. simici showed a rather unimolal activity with a maximum in June. The number of captured $P$. alexandri and $P$. sergenti was not large enough to draw conclusions. $S$, minuta, the only representintive of the genus Sergentomlia, had its maximum activity in September.

\section{DISCUSSION}

T his is the first extensive and full-season study on sandflies that has ever been carried out in an urban and peri-urban environment in Greece.

$P$. papatasi represented about $1 / 5$ of the collected specimens and was found in more than $50 \%$ of the sampled localities. This species appeared to be much more common in this study than in previous ones conducted by the same merhod in different parts of Greece, except eastern Crete and Karpathos (Léger et al. 1979; Pesson et al., 1984; Léger et al.. 1992; Pesson et al.. 1993). This scarcity maly be due to the low number of domestic sites explored by these researchers. It is noteworthy that in studies clone in Athens before and after the anti-malaria residual insecticicle campaign, P. papatasi was the only or the main species present in Athens (Caminopetros, 1934, 1935; Hertig, 1949; Hadjinicolaou, 1958). The extreme abundance of this anthropophilic species in these early studies is probably due to the limited number of localities explored and to the different proceclures of collection used (mainly manual capture, often done on the internal walls of houses). The anthropophilic and domestic behaviour of this species was noted in Yugoslavia where $P$. papatasi represents $80-90 \%$ of the captures in houses but only $20 \%$ of the captures in stables and chicken-coops (Simic, 1951).

$P$. papalasi is considered to be the main vector of Leishmania major and sandfly fever. However, $L$. major has never been isolated from sandflies, clogs or man in Greece. P. sergenti, which had been incriminated as the main vector of $L$. tropica in Crete (Adler et al., 1938), was very rare in our study. The scarcity of this species could explain the absence or very low frequency of cases of cutaneous leishmaniasis in the Athens Basin.

The absence of $P$. alexandri and $P$. simici from the highly urbanized center transect is interesting. In Southern Morocco this species is chiefly present outside the concrete settlements in wild areas (Rioux $e t$ al. 1984 ), in agreement with our results.

$P$. neglectus, the most common species in our study, was suspected as a vector of visceral leishmaniasis in Athens because of its abundance in the vicinity of the Pasteur Institute, where several cases of infantile kalaazar occurred (Adler and Theoclor, 1935). It is also the only sandfly species from which a Leishmania infantum has been isolated in Greece (Léger et al., 1988; Garifallou et al., 1989). Thus, it appears to be the best candiclate for the transmission of VL in the metropolitan area. The other member of the subgenus Lamroussius in Athens. P. tobbi. was less abundant than $P$. neglectus and is probably less important in the transmission of $\mathrm{VL}$ in the region. P. tobbi was experimentally infected with $L$. infantum and was considered as the probable vector of this parasite in Cyprus (Adler, 1945).

S. minuta is the only species of the genus Sergentomyia present in Athens. S. dentata. often more abundant than $S$. mimula in other parts of Greece (Léger et al., 1979; Pesson et al., 1984), has never been collected in the region of Athens.

The unimodal seasonal activity of $S$. minuta with its peak in late summer was also observed in Tunisia, while the bimodal activity with two peaks in spring and autumn of $P$. neglectus and $P$. tobbi is similar to the activity of two other species of the subgenus Larroussins, $P$. perniciosus and $P$. perfilieut, present in that country (Croset et al., 1978).

The results of our study indicate that there exist significant foci of sandtly breeding in the Greater Athens area. The vectors of $\mathrm{VL}(P$. neglectus, $P$. tobbi) and sandfly fever ( $P$. papatasi) are distributed widely and 


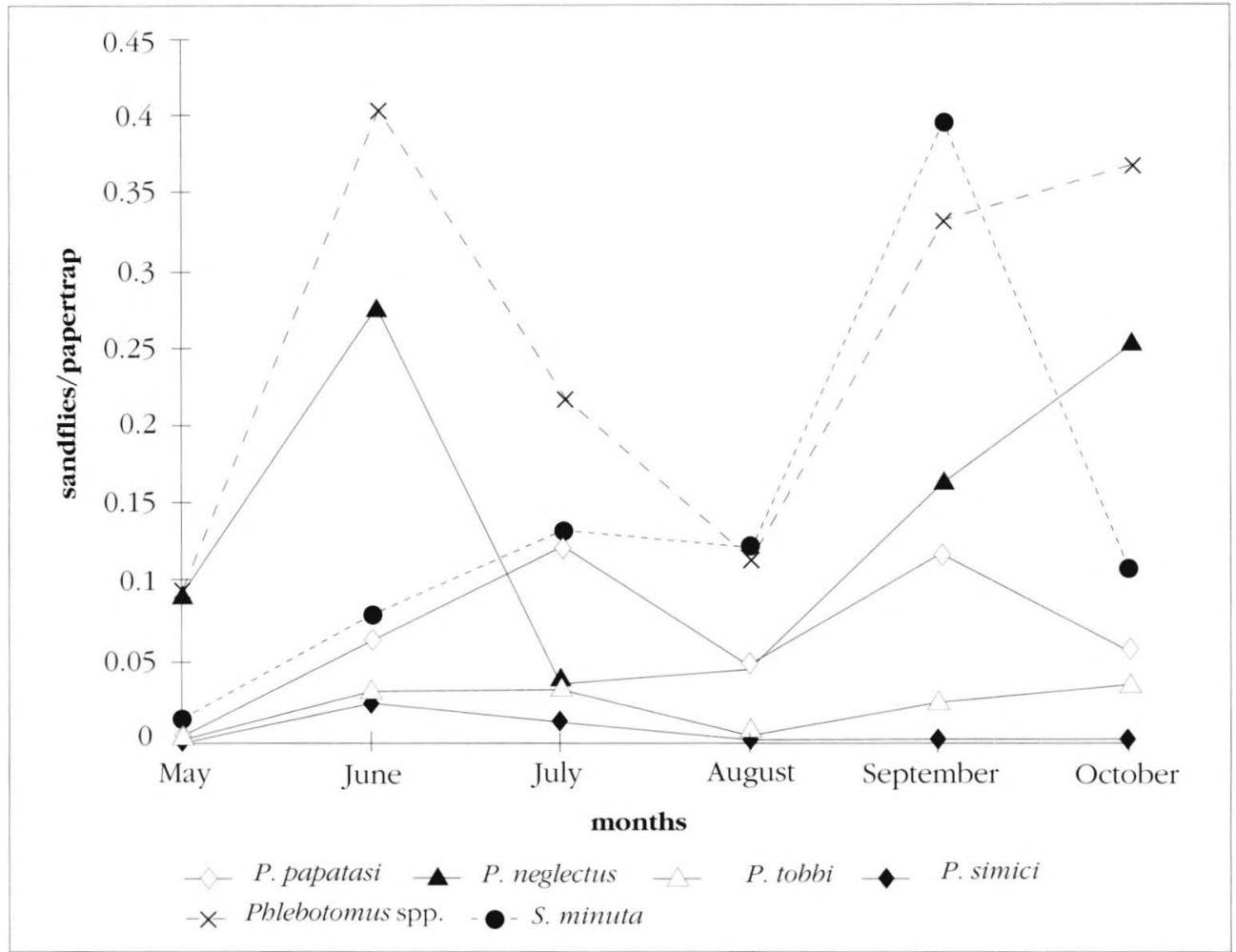

Fig. 5 - Fluctuations in seasonal density of sandities in the Greater region of Athens.

\begin{tabular}{|c|c|c|c|c|c|c|}
\hline SANDFLY SPECIES & Nbr sf & $\%$ & $\mho^{\prime}$ & 99 & $\left(\begin{array}{c}q 9 / \\
\left(00^{2}+q 0\right.\end{array}\right)$ & $\begin{array}{l}\text { Nbr } \\
\text { local. }\end{array}$ \\
\hline Phlebotomus (Pblebotomus) papatasi & 541 & 34.1 & 414 & 127 & 0.23 & 40 \\
\hline Phlebotomus (Paraphlebotomus) alexandri & 30 & 18.4 & 28 & 2 & 0.07 & 9 \\
\hline Pblebotomus (Paraphlebotomus) sergenti & 13 & 6.2 & 10 & 3 & 0.23 & 3 \\
\hline Pblebotomus (Larroussius) neglectus & 1002 & 1.7 & 915 & 87 & 0.09 & 55 \\
\hline Pblebotomus (Larroussius) tobbi & 182 & 1.0 & 163 & 19 & 0.10 & 27 \\
\hline Pblebotomus (Adlerius) simici & 50 & 0.4 & 46 & 4 & 0.08 & 16 \\
\hline Sergentomyia (Sergentomyia) minuta & 1122 & 38.2 & 747 & 375 & 0.33 & 40 \\
\hline Total & 2940 & 100.0 & 2323 & 617 & 0.21 & 64 \\
\hline
\end{tabular}

Table I. - Sandly species of the Greater Athens region

Legend : Nibr sf. number of sindflies; \%, percentige on the total number of collected specimens: $Q$. number of males: $Q$. number of females: $Q \sigma o+Q$ proportion of females; thr local.. number of localities they were found

\begin{tabular}{|l|r|r|r|r|c|}
\hline \multirow{2}{*}{\multicolumn{1}{|c|}{ SANDFLY SPECIES }} & \multicolumn{5}{|c|}{ MEAN MONTHLY DENSITY } \\
\cline { 2 - 6 } & $\begin{array}{c}\text { West } \\
\text { transect }\end{array}$ & $\begin{array}{c}\text { East } \\
\text { transect }\end{array}$ & $\begin{array}{c}\text { Center 1 } \\
\text { transect }\end{array}$ & $\begin{array}{c}\text { Center 2 } \\
\text { transect }\end{array}$ & $\begin{array}{c}\text { Athens } \\
\text { Total }\end{array}$ \\
\hline Phlebotomus (Phlebotomus) papatasi & 0.072 & 0.136 & 0.006 & 0.015 & 0.090 \\
Phlebotomus (Paraphlebotomus) alexandri & 0.011 & 0.001 & 0.000 & 0.000 & 0.005 \\
Pblebotomus (Paraphlebotomus) sergenti & 0.005 & 0.000 & 0.002 & 0.000 & 0.002 \\
Phlebotomus (Larroussius) neglectus & 0.129 & 0.208 & 0.169 & 0.131 & 0.168 \\
Phlebotomus (Larroussius) tobbi & 0.018 & 0.052 & 0.007 & 0.004 & 0.031 \\
Phlebotomus (Adlerius) simici & 0.007 & 0.015 & 0.000 & 0.000 & 0.009 \\
Total Pblebotomus spp. & $\mathbf{0 . 2 4 1}$ & $\mathbf{0 . 4 1 3}$ & $\mathbf{0 . 1 8 3}$ & $\mathbf{0 . 1 5 0}$ & $\mathbf{0 . 3 0 4}$ \\
Sergentomyia (Sergentomyia) minuta & 0.264 & 0.112 & 0.018 & 0.252 & 0.175 \\
Unknown & 0.009 & 0.017 & 0.005 & 0.014 & 0.013 \\
\hline Total & $\mathbf{0 . 5 1 4}$ & $\mathbf{0 . 5 4 2}$ & $\mathbf{0 . 2 0 7}$ & $\mathbf{0 . 4 1 6}$ & $\mathbf{0 . 4 9 2}$ \\
\hline
\end{tabular}

Table II. - Mean monthly density of the collected sandflies, per transect and total, for the period June-October 1992. 
thus the potential exists for transmission of these diseases under some circumstances. We believe that the risk is greater on the outskirts of the city and less in the central part where urbanisation and pollution have created unfavourable conditions for the survival of sandflies.

\section{ACKNOWLEDGEMENTS}

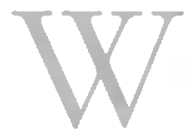

e would like to thank Professors $N$ Léger and 13. Pesson, as well as Dr. B. Chaniotis for assistance in the conduct of our research project. We would also like to thank $\mathrm{G}$ Gozalo and A. M. Aransay for their technical assistance. This study was partially financed by a STD program.

\section{REFERENCES}

Aldifr S. : The sandflies of Cyprus (Diptera). Bull. Ent. Res., $19+5,36,497-511$

AlDLR S. and THEODOR O. : Investigations on Mediterranean kala azar. Vill. Further observations on Mediterranean sandflies. Proc. Rol. Soc, (13). 1935, 116, 505-515

Adier S., Thfolom O. and WITEnberg G. : Investigations on Mediterranean kala azar. XI. A study of leishmaniasis in Caneal (Crete), Proc. Roy. Soc. (B), 1938, 125, 49!-516.

Aravandivos A. : Contribution a l'historique de la lesishmaniose interne. Bull. Soc. Path. Furot., 1916, 9. 10-13

Canisoplitros J. : Sur la faune des phlébotomes de Grèce. Leur distribution clans les foyers de kala-azar. Bull. Soc. Path. Furot. 1934, 27, $550-455$.

Canivopi:tros J. : Acklition à la liste des phléboromes signalés pour la première fois en Grèce. Bull. Soc. Path. Exot., $1935,28,41-46$.

Cardanatis J.P. : Des piroplasmiases et leishmaniases. $Z$ bl. Bakt. Abt. I. Orig., 1911, 60(6), 511-523

Cardanates J.P. : Le kala-azar est en Grèce une maladie a cas sporadiques. Mégalosplénies de cause inconnue. Bull. Soc. Path. Exot., 1912, 5, 489-491.

CARDAMATIS J.P. : Etude préliminalire sur les Phlélotomes de Grèce. Bull. Soc, Path. Exot. 1931, 24, 287-292.

Croset H., Riol X J.-A., Léger N., Holta R., Cald-Sol'ssi M. BemmansotR $N$ and Maistre $M$. : Les méthodes d'échantillonage dess populations de phlébotomes en région méditertanéénne. In : Colloque Int. CNRS, n 239. Ecologie des leishmanioses. Montpellier. 18-24 aô̂t 1974. 1977. Pp. 139-151

Croset I1. RiotX J.-A., Masstre M. and Bayar N.: Les phlébotomes de Tunisie (1)iptera, Phlebotomidate). Mise au point systématique, chorologique et éthologique. Ann. Parasitol Illam. Comp., 1978, 6.3(6), 711-749.

Garifallot A., hadilantomiol M.. Scinder L.F., Yital. B.. Warbirg A., Jacobson R.L., Pateraki E., Patrikosisis M.,
Schilis Y Y and Si:RIt: C. : Epidemiology of human and canine leishmaniasis of the island of Zakinthos. $I n: D$ ). ' Hart (Editor), Leishmaniasis. Plenum Publishing Corporattion, 1989, pp. 1011-1015.

HATINICOLAOI J. : Present status of Phlebotomms in certain areas of Greece. Bull. Whd Hith Org. 1958, 19, 967-979).

HekTi M. : Phlebotomis and residual D.1).T in Greece and Italy. Am. J. Trop. Hed. 1949, 29,773-809

Legiar N.. Gramicia M. Gradont L.. Madulo-Lfbloni) G.. Plesion B., Ferté H., Bollanger N., Killick-Kendrick R. and Killick-KExIrack M. : Isolation and typing of Leishmania infantmm from Phlebotomus neglectus on the island of Corfu, Greece. Trans. Royl. Soc. Trop. Med II.g., $1988,82,419-420$.

Líger N., Pesson B and Mandio-Lebionis G. : Les phléhotomes de Grèce. Biol. Gallo-Hellenica, 1986, 112), 165192.

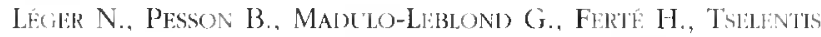
I. and Havtonion M. : Les phlébotomes de Crète, $I n$ : Proc. 5th Int. Congr. Zoogeogr. Ecol. Greece and Adjacent Regions, Heraklion, 16-20 April 1990, Biol. Gallo-Hollenica, 1992, in press.

Legilir N., Saratsiotis A. Pesson B. and Leger P. : La leishmalniose en Grèce. Résultats d'une enquête entomologiqule effectuée en juin 1977. Ann. Parasitol. Ham. Comp. 1979, 54(1), 11-29

Mavromatis G. : Le bioclimat de la Grèce, Relations entre le climat et la végétation naturelle. Cartes bioclimatiques [in Greek, with French summaryl. Dasiki Ererna. 1980, 1, 63 pp. +3 maps.

Orpuanids Z. : Epiclemiological. clinical and immunological study of visceral leishmaniasis in Greece lin Greek, with English summary]. Med. Thesis, Iniversity of Athens. school of Medicine, 1979, 79 pp.

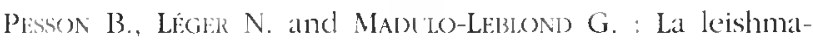
niose en Grèce: Le's phlébotomes des îles ioniennes et dè la mer Egée. Ann. Parasitol. Hum. Comp., 1984, 59(3), $277-296$.

Presod B., Léger N., Madilo-Lfblond G., Frrté H., Thithe tis 1., Papadopol los 13. and Périľres J : Spéciation et vicariance chez les phlébotomes des îles greccues. $I n$ : Proc. oth Int. Congr. Zoogeogr. Ecol. Greece and Adjacent Regions. Thessaloniki, 5-9 April 1993, in press.

Riolx J.-A., Croset H. and Lavotte G. : Ecologie d'un foyer méditerranéen de leishmaniose viscérale. Essai de modélisation. In : Collogue Int. CNRS. no 239. Ecologie des leishmanioses, Montpellier, 18-24 aloût 1974, 1977, pp. 29) (6-305.

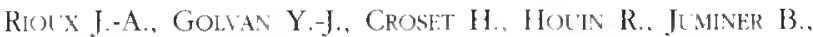
BaiN O. and Tot $\mathrm{S}$. : Ecologie des leishmanioses dans le sud de la Frances. 1. Les Phlébotomes. EchantillonageEthologie. Ann. Parasit. Hum. Comp. 1967, 42 (6), 561603.

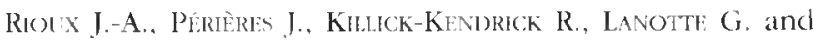
[Bailly M. : Ecologie des leishmanioses dans le sud de la France. 17. Echantillonage de Phlélotomes par le pro- 
cédé des pièges adhésifs. Comparaison avec la technique de capture sur appât humain. Ann. Parasit. Hum. Comp.. 1982, $57(6), 631-635$.

RIOLX I.-A., Rispail P.. LaNotTr: G. and Lepart J. : Relations phlébotomes-bioclimats en écologie des leshmanioses. Corollaires épidémiologiques. L'exemple du Maroc. Bull. Soc. Bol. Fr. 1984, 131, Actlacl. Bot., 2/3/4, 549-557.

Sinic T. : La faune des phlébotomes de Yougoslavie. VIIe partic. - L'étendue des espèces de phlébotomes et leur proportion dans les différentes régions du pays. Bull. Acad. Serb. Sci., Cl. Sci. Med, 1951, 3. 125-132.

TSelentis Y., Orphanides Z.. Mfillsinos K. and Trichiopolilos D. : Répartition géographiçue de la leishmaniose viscérale en Grèce. Congr. Soc. Franc. Parasitol., 1979. Abstracts. p. 4.

Tzamol'ranis N. : Rapport dactivité du laboratoire de parasitologie Leishmanioses. Archs Inst. Pasteur Hellen.. 1979, 25. $159-165$.

Tzamol'ranis N., Schnur L. F., Garifallol A., Patiraki E. and SERIE C. : Leishmaniasis in Greece. I. Isolation and identification of the parasite causing human and canine visceral leishmaniasis. Ann. Trop. Hed. Parasitol.. 1984, 78 (4), 363-368.

Accepté le 7 avril 1994 